\title{
Technological innovations in animal production related to environmental sustainability ${ }^{1}$
}

\author{
Inovações tecnológicas na produção animal relacionadas à sustentabilidade ambiental
}

\author{
KEBREAB, Ermias ${ }^{2 *}$; MORAES, Luis ${ }^{2}$; STRATHE, Anders ${ }^{2}$; FADEL, James ${ }^{2}$
}

\author{
${ }^{1}$ Revisão apresentada no Congresso Brasileiro de Zootecnia (ZOOTEC 2011). \\ ${ }^{2}$ University of California, Department of Animal Science, Davis, United States of America. \\ *Endereço para correspondência: ekebreab@ucdavis.edu
}

\section{SUMMARY}

According to FAO, meat production will double by 2050 to meet the demand of growing and more affluent population. The soaring demand presents an environmental challenge for intensive animal production. Greenhouse gas emissions (GHG), particularly methane $\left(\mathrm{CH}_{4}\right)$ increases as animal numbers increase, however, mitigation strategies such as dietary manipulation (e.g., lipid supplementation), ionophores, defaunation and biotechnologies can be used to reduce emissions per animal. Emissions from manure storage can also be reduced using biological and thermochemical conversion technologies with added benefit of producing bio-energy while treating livestock wastes. At the animal level, reduction of overfeeding protein and balancing the amounts of protein degraded in rumen and those allowed to bypass the rumen will reduce $\mathrm{N}$ excretion. Synchronizing energy and protein supply to animals also offers better utilization of nutrients with concomitant decrease in urine $\mathrm{N}$, which contains high levels of urea that can be converted into ammonia when mixed with feces. Phosphorus in manure represents a significant renewable resource and there are several technologies that remove and recover $\mathrm{P}$ from manure including chemical precipitation, biological $\mathrm{P}$ removal and crystallization. The development of technologies for GHG and nutrient reduction offers the opportunity for environmental sustainability.

Keywords: entenic fermentation, methane, ruminants.

\section{RESUMO}

De acordo com a FAO, a produção de carne deve duplicar até 2050, devido à grande demanda e enriquecimento da população. Essa crescente necessidade apresenta um desafio ambiental para a produção intensiva de animais. A emissão de gás do efeito estufa, particularmente metano $\left(\mathrm{CH}_{4}\right)$, se eleva com o aumento do número de animais, entretanto, estratégias de mitigação, tais como a manipulação da dieta, por exemplo, suplementação lipídica, ionóforos, defaunação e biotecnologias podem ajudar a reduzir a remessa por animal. Emissões por armazenamento de esterco também podem ser reduzidas se utilizarem tecnologias biológicas e termoquímicas com o benefício adicional de se produzir bio-energia durante o tratamento de resíduos animais. No que diz respeito ao animal, a redução da superalimentação proteica e a manutenção do equilíbrio entre proteína degradada no rúmen e proteína bypass podem reduzir a excreção de nitrogênio. Balanceamento de energia e suplementação proteica dos animais também podem oferecer melhor utilização dos nutrientes e, concomitantemente, diminuir o nitrogênio na urina, que contém altos níveis de ureia que, por sua vez, pode ser convertida em amônia quando misturada às fezes. Fósforo nos resíduos (estrume) representa um importante recurso renovável, e várias tecnologias existem para remover e recuperar esse mineral sem excluir precipitação química, remoção biológica e cristalização. $\mathrm{O}$ desenvolvimento de tecnologias relacionadas ao efeito estufa oferece oportunidade para a sustentabilidade ambiental.

Palavras-chave: fermentação entérica, metano, ruminantes. 


\section{INTRODUCTION}

Globally, there has been an increase in public concern about environmental damage instigated by intensive animal feeding operations. This increased public concern has led some countries such as the Netherlands to introduce legislation (JONGBLOED \& LENIS, 1998). The main concerns related to large scale animal production are the production of Greenhouse gas emissions (GHG) and ammonia $\left(\mathrm{NH}_{3}\right)$, which are linked to air quality degradation and global warming as well as the impact of nutrient losses on water quality. For example, the global dairy sector contributes $4.0 \%$ of globally produced anthropogenic GHG, with the majority of these gases produced on the dairy farm (FAO, 2011). Methane $\left(\mathrm{CH}_{4}\right)$ is the main GHG gas eructated from dairy farms, which is 25 times more effective in trapping heat in the atomsphere than carbon dioxide over 100 year period (IPCC, 2006). The main source of nutrient pollution from animal production is $\mathrm{N}$ and $\mathrm{P}$ excretion in excess of crop removal. Although $\mathrm{N}$ is a central element for plants and animals, it is highly mobile and high concentrations can be toxic and cause environmental degradation. Phosphorus is an essential nutrient that contributes to agricultural development. However, its release in the environment is associated with depletion of nonrenewable inorganic $\mathrm{P}$ sources and causing eutrophication. Steen (1998) estimates global phosphate reserves to be depleted in 50 to 100 years.

The objective of this study is to review and discuss technological innovations that are used to mitigate environmental pollution and increase sustainability of animal production.

\section{GREENHOUSE GAS EMISSIONS}

Greenhouse gases absorb solar radiation reflected from earth's surface, contributing to the global warming effect. Greenhouse gas emissions from the agricultural sector that are related to animal production comprise $\mathrm{CH}_{4}$ directly emitted from domestic animals, $\mathrm{CH}_{4}$ and $\mathrm{N}_{2} \mathrm{O}$ emitted from manure and grazed lands, and $\mathrm{N}_{2} \mathrm{O}$ emitted from soils after application of manure (KEBREAB et al., 2006).

Livestock production, especially ruminants, contributes to $\mathrm{CH}_{4}$ emissions worldwide significantly. Methane is also associated with dietary energetic losses, which are generally between 2 and $12 \%$ of the ingested gross energy (JOHNSON \& JOHNSON, 1995). Carbohydrates are fermented in the rumen, producing relatively large quantities of $\mathrm{CH}_{4}$ when compared to non-ruminant animals. Agriculture accounts for $50 \%$ of anthropogenic $\mathrm{CH}_{4}$ emissions in the world (IPCC, 2006) and beef cattle were the largest contributor of enteric $\mathrm{CH}_{4}$ emissions in the United States, accounting for $71 \%$. Dairy cattle accounted for $25 \%$, and the remaining were produced by enteric fermentation of other animals (EPA, 2007).

Enteric fermentation. Methane in ruminants is produced during the fermentation process of substrates in the rumen, especially structural carbohydrates, by the action of a group of Archaea denominated methanogens. Methanogens are composed basically of Methanobrevibacter, Methanobacterium, Methanosarcina, and Methanomicrobium (BALCH et al., 1979). Most of methanogens utilize hydrogen originated in the production of volatile fatty acids (VFA) in rumen fermentation process, to reduce $\mathrm{CO}_{2}$ to $\mathrm{CH}_{4}$. However some 
methanogens can utilize other substrates to produce $\mathrm{CH}_{4}$, such as the utilization of formate as a hydrogen source (HUNGATE et al., 1970). Protists (commonly referred to protozoa) also have an important role in the $\mathrm{CH}_{4}$ ruminal production since methanogens can bind to protozoa and transfer hydrogen (SHARP et al., 1998). Mitigations strategies to reduce $\mathrm{CH}_{4}$ emissions from ruminants have become an important tool to decrease environmental impacts of livestock production and also to increase energetic efficiency of feed utilization. Hook et al. (2010) and Martin et al. (2010) reviewed mitigation strategies focused on dietary manipulation and biotechnological and management techniques. According to Martin et al. (2010), ideal $\mathrm{CH}_{4}$ mitigation strategies should decrease emissions by modifying hydrogen production and utilization without decreasing nutrient digestibility. Hydrogen utilization should be shifted towards the formation of other biochemical compounds to maintain rumen $\mathrm{pH}$ and not decrease the rate of carbohydrate fermentation. Also, mitigation strategies should be economically feasible to be adopted by producers. Methane abatement technologies can be divided into four main categories: dietary manipulation, use of ionophores and other compounds such as organic acids, defaunation, and use of biotechnologies.

Dietary manipulation. Diet composition plays an important role in $\mathrm{CH}_{4}$ production in the rumen. The profile of VFA produced in the rumen is dependent on the form of dietary carbohydrates fermented. Ruminal fermentation of structural carbohydrates promotes a greater production of acetate, in which hydrogen is formed and can be used by methanogens to produce $\mathrm{CH}_{4}$. The fermentation of non- structural carbohydrates favors the production of propionate, which acts as a proton sink to sequester hydrogen. Forages usually have a higher composition of structural carbohydrates, therefore, are likely to increase the proportion of acetate and availability of hydrogen for $\mathrm{CH}_{4}$ production. However, dietary manipulation only has a limited role in reducing $\mathrm{CH}_{4}$ emissions, especially for lactating dairy cows, because a minimum amount of fiber in the diet is required for maintenance of chewing activity, stimulation of saliva production and buffering the rumen $\mathrm{pH}$. Structural carbohydrate's physical form is also important because fiber from grains and by-products are usually not as effective as fiber from forages in stimulating chewing activity and maintaining milk fat percentage (ARMENTANO \& PEREIRA, 1997) by maintaining acetate levels in the rumen. Excessive levels of dietary nonstructural carbohydrates can lead to greater VFA production that may exceed the absorption capacity of the rumen wall. The increased VFA production decreases rumen $\mathrm{pH}$ and promotes the formation of lactate which further decreases rumen $\mathrm{pH}$, impairing rumen bacterial activity and increasing the incidence of ruminal acidosis (PLAIZIER et al., 2008).

Lipid supplementation has been studied as a mitigation strategy for $\mathrm{CH}_{4}$ production in the rumen due to distinct forms of action (JOHNSON \& JOHNSON, 1995). The first hypothesis is that the supplemented unsaturated fatty acids utilize hydrogen through the biohydrogenation process in the rumen, in which unsaturated fatty acids are reduced to partially or completely saturated fatty acids (WU \& PALMQUIST, 1991). Therefore, the fatty acid chain length and the degree of unsaturation would have an important 
role in determining the amount of hydrogen utilized in biohydrogenation. A second hypothesis is that the inclusion of lipids in the diet can shift VFA production to propionate, increasing the utilization of hydrogen thereby reducing its availability for $\mathrm{CH}_{4}$ production. A third hypothesis is that lipids would have a negative impact in rumen protistan-methanogen associations (CZERKAWSKI, 1966) inhibiting $\mathrm{CH}_{4}$ production and protist activity in the interspecific hydrogen transfer reactions. A meta-analysis by Eugene et al. (2008) found that emissions decreased by $9 \%$ when the dietary ether extract increased from 2.5 to $6.4 \%$. Beauchemin et al. (2008) found that $\mathrm{CH}_{4}$, in $\mathrm{g} / \mathrm{kg}$ of DMI, was reduced by $5.6 \%$ for each additional percent of supplemental fat based on dairy, beef, and sheep data. Lipid supplementation can be a promising technique to reduce enteric $\mathrm{CH}_{4}$ production; however, the modification of ruminal environment by the fat supplementation is an important point because excessive dietary fat (greater than 6-7\%) can compromise fiber digestion.

Ionophores and other compounds. The use of ionophores in ruminant diets has been studied in relation to improvement of feed utilization (RUSSELL \& STROBEL, 1989) and manipulation of ruminal fermentation, decreasing the incidence of acidosis (TUNG \& KUNG, 1993). However, with increased concern of GHG emissions, the ability to reduce $\mathrm{CH}_{4}$ emissions in the rumen by ionophores, especially monensin, is of interest. Monensin alters the transport of ions, especially sodium, through the cell wall membrane, causing an inhibitory effect in gram positive bacterial population. The reduction of $\mathrm{CH}_{4}$ emissions with the use of monensin has been attributed to the inhibitory effect on ruminal methanogens and in the decrease of hydrogen supply for methanogenic population. Hook et al. (2009) studied the long term effect of monensin and after 6 months, the quantity and diversity of ruminal methanogens was not affected by monensin. Therefore, the reduction in $\mathrm{CH}_{4}$ emissions with monensin supplementation seems to be more a result of the inhibition of gram positive bacteria in the rumen, shifting VFA from acetate to propionate and also decreasing the supply of hydrogen to the methanogenic population. Odongo et al. (2007) reported a 7\% decrease in $\mathrm{CH}_{4}$ emissions without compromising intake or milk yield after 6 month supplementing monensin at $24 \mathrm{mg} / \mathrm{kg}$ of diet DM. Similar results were reported by McGinn et al. (2004) with a decrease of $8.6 \%$ of $\mathrm{CH}_{4}$ emissions per $\mathrm{kg}$ of DM intake with the use of monensin in beef cattle. The quantity of monensin supplied has an important role in $\mathrm{CH}_{4}$ reduction. Doses lower than $1 \mathrm{ppm}$ (WAGHORN et al., 2007) and 20ppm (VAN VUGT et al., 2005) did not decrease $\mathrm{CH}_{4}$ emissions per unit of DM intake of dairy cows in the reported studies. Guan et al. (2006) found that monensin supplementation reduced $\mathrm{CH}_{4}$ emissions up to $30 \%$ when $33 \mathrm{mg} / \mathrm{kg}$ of diet DM was fed to beef cattle, however, the reduction in $\mathrm{CH}_{4}$ emissions was only observed for 2 months. Johnson \& Johnson (1995) discussed the persistency of the reduction in $\mathrm{CH}_{4}$ emissions, stating that reductions in $\mathrm{CH}_{4}$ emissions usually last for 2 weeks and returns to previous levels probably due to the adaptation capacity of methanogen population or the hydrogen producers. These results suggest that monensin can be used to reduce $\mathrm{CH}_{4}$ over a short period of time, such as early lactation, but this reduction in $\mathrm{CH}_{4}$ cannot be sustained for longer periods.

The search for specific compounds in animal diets that could decrease $\mathrm{CH}_{4}$ 
production in ruminal fermentation has increased over the years. Plant extracts such as essential oils, tannins and saponins have been studied as natural compounds that could assist in the reduction of enteric $\mathrm{CH}_{4}$ emissions. The reduction of $\mathrm{CH}_{4}$ emissions with condensed tannins may be caused by an inhibition of rumen methanogens and by a decrease in the hydrogen available for methanogens (TAVENDALE et al., 2005). However, most of the trials utilizing tannins were conducted in vitro and the reported in vivo trials present different results regarding changes in feed digestibility (MARTIN et al., 2010). Puchala et al. (2005) measured $\mathrm{CH}_{4}$ emissions, in an open circuit respiration calorimeter from goats fed a high tannin forage (17\% DM) vs. a forage with $0.5 \%$ DM condensed tannins and $\mathrm{CH}_{4}$ emissions were reduced from 16.2 to $6.9 \mathrm{~g} / \mathrm{kg}$ of $\mathrm{DM}$ intake respectively. VFA production in the rumen was not altered nor was feed digestibility. However, results are not consistent. Beauchemin et al. (2007) reported that Angus steers fed up to $2 \%$ of dietary DM of quebracho tannin extract did not result in a reduction of $\mathrm{CH}_{4}$ emissions and apparent crude protein digestibility decreased $15 \%$. The reports for tannin research shows promise but there is inconsistency in the results which may be due to the form that the tannins are fed. Also, the effects of tannins on protein digestibility can impair the utilization of the compound in animal diets. Compounds present in essential oils also have been examined as rumen fermentation modifiers. Antimicrobial properties present in these oils are thought to reduce hydrogen supply for rumen methanogenic population as discussed by Hook et al. (2010). Busquet et al. (2005) found a decrease in $\mathrm{CH}_{4}$ emissions when garlic oil was added at
$300 \mathrm{mg} / \mathrm{L}$ of rumen fluid in lactating dairy cows fed rations with 50:50 forage concentrate ratio. McGinn et al. (2004) reported that sunflower oil reduced $\mathrm{CH}_{4}$ emissions by $22 \%$, however, NDF digestibility also was reduced by $20 \%$ in growing beef cattle. Therefore, results with these compounds show promise but are not consistent and require further investigation before practical implementation.

Defaunation. Complete or partial elimination of protists from the rumen is termed defaunation. The role of defaunation in reduction of $\mathrm{CH}_{4}$ emissions is based on the supply of hydrogen to methanogenic population by rumen protists, through the hydrogen transfer process (SHARP et al., 1998). Defaunation of ciliate protists in the rumen of steers increased propionate concentration, whereas steers with a normal protist population had a greater concentration of butyrate in the rumen (WHITELAW et al., 1984). Methane emissions were reduced from 11.5 to 6.68 $\mathrm{MJ} / 100 \mathrm{MJ}$ of GE with defaunation. Several additives and substances can promote rumen defaunation, as discussed above (monensin, lipid supplementation) and results are usually dependent on diet composition (HEGARTY, 1999). The viability of rumen defaunation can be compromised with the adaptation capacity of rumen protists (as discussed for monensin). Moreover, the maintenance of defaunated animals can be a difficult process (BIRD et al., 2010) and nutrient digestibility can be impaired with the reduction of rumen protists.

Biotechnologies. Several biotechnologies have been tested to reduce $\mathrm{CH}_{4}$ production in the rumen. Wright et al. (2004) reduced $\mathrm{CH}_{4}$ production by $8 \%$ with the use of a vaccine to suppress methanogens. The development of such vaccines rely on the identification and cultivation of different strains of 
methanogens, however, not all methanogens have been identified or cultivated (WHITFORD et al., 2001). Differences in rumen methanogens due to feeds, climate and other aspects in different parts of the world could limit the action of vaccines in different regions in which the vaccines were developed (WRIGHT et al., 2007). Cooprider et al. (2011) achieved 31\% reduction in $\mathrm{CH}_{4}$ emissions from feedlot cattle by implanting them with $100 \mathrm{mg}$ trenbolone acetate and $14 \mathrm{mg}$ estradiol benzoate and also adding monensin to the diet. Other technologies, such as passive immunization, bacteriocins were discussed by Martin et al. (2010) and generally results are not persistent over time or consistent between experiments.

Manure management and land application. Alternative uses of manure can be separated into three categories: conversion and use as an energy source; conversion to value-added products; and innovative and emerging products. Many technologies and strategies already exist for converting animal manure into energy and other valuable products. New technologies are also being developed with better efficiencies and new products. Energy products that can be derived from manure include heat and biofuels, which includes gaseous (e.g. biogas from anaerobic digestion), liquid (e.g. alcohols from fermentation) and solid (e.g. densified pellets made from fibers) fuels. Biological and thermochemical conversion technologies can be applied to produce bio-energy while treating livestock wastes.

Anaerobic Digestion. Animal manure has complex chemical composition and high moisture content, therefore, biogas production from anaerobic digestion appears to be the most energy-efficient choice (CAES, 2008). A properly functioning anaerobic digester can provide numerous benefits at farm, local, and environmental levels. These benefits include: odor control; reduction of nuisance gas emissions; potential pathogen kill; reduction of wastewater strength (oxygen demand); onversion of organic $\mathrm{N}$ into plant available $\mathrm{NH}_{3}-\mathrm{N}$; preservation of plant nutrients (e.g., $\mathrm{N}$, $\mathrm{P}, \mathrm{K}$ ) for use as a high quality fertilizer; and production of a renewable energy source-biogas, which typically contains $50-70 \% \quad \mathrm{CH}_{4}$ with the rest being primarily $\mathrm{CO}_{2}$ and impurities. Biogas can be upgraded to biomethane by removing moisture, $\mathrm{CO}_{2}$ and impurities and supplied to existing and future natural gas distribution systems (CANTRELL et al., 2008). The disadvantages include high initial capital investment; and high standards of maintenance and management.

Covered lagoon. The most common way to store manure from large animal facilities is using open-air, anaerobic lagoons. Although these are low maintenance systems, they results in emissions for GHG such as $\mathrm{CH}_{4}$ and $\mathrm{CO}_{2}$, and other odorous intermediate compounds such as hydrogen sulfides and $\mathrm{NH}_{3}$. Covering the lagoon using a floating impermeable cover can reduce GHG and air pollutants, and harvest biogas (DESUTTER \& HAM, 2005). The Alberta government recognizes covering lagoon as GHG reducing technology and farmers can get carbon credit for covering their manure lagoons and flaring the biogas trapped under the cover (CLIMATE CHANGE CENTRAL, 2011).

Therochemical conversion (TCC). The technique is a high-temperature chemical reforming process that breaks apart the bonds of organic matter and reforms these intermediates into char, synthesis gas and highly oxygenated bio-oil. In addition to TCC being a mass consumer of a manure's organic portion 
that extracts all available energy, TCC processing has a number of other benefits and advantages: small footprint; efficient nutrient recovery; no fugitive gas emissions; short processing time in the order of minutes; capability of handling a variety feedstocks and blends; and high-temperature elimination of pathogens and pharmaceutically active compounds (CANTRELL et al., 2007). One of the processes identified for converting livestock manures into a value-added renewable energy product are pyrolysis (CANTRELL et al., 2007). Pyrolysis uses heat and a non-oxygen atmosphere to convert the organic portion of a feedstock into a mixture of char and volatile gases containing both noncondensable vapors and condensable tars (oxygenated hydrocarbons), which form a combustible pyrolytic oil or biooil (MOHAN et al., 2006). Slow pyrolysis converts animal wastes into char, providing farmers with potential economic benefits due to energy production and carbon credits generated from carbon sequestration. Char can also be applied to soil as a soil amendment to improve fertility (ANTAL \& GRØNLI, 2003).

Algal $\mathrm{CO}_{2}$ removal. Carbon dioxide is a major component in the product gases from anaerobic digestion and thermochemical conversion processes. Since an increased atmospheric concentration of $\mathrm{CO}_{2}$ is considered one of the main causes of global warming (SCHNEIDER, 1989), it is important to recover $\mathrm{CO}_{2}$ to limit short-term release. By naturally fixing atmospheric $\mathrm{CO}_{2}$ via photosynthesis 10 times more efficiently than terrestrial plants (USUI \& IKENOUCHI, 1997), algae can rapidly generate both algal biomass and intracellular oil (MIAO \& WU, 2006). These algal products can then be harvested and converted into multiple value-added products.

\section{NUTRIENT EXCRETION}

Reduce overfeeding and balancing (RUP). Reducing $\mathrm{N}$ excretion from livestock is one way to reduce nutrient loading in the environment. Urea excreted in urine, if mixed with feces, is converted to $\mathrm{NH}_{3}$ and volatilized because of high urease activity in feces (MUCK, 1982). Indigestible dietary protein is excreted in feces and can be leached to water sources promoting eutrophication (TAMMINGA, 1992). Animal $\mathrm{N}$ requirements are based on metabolizable protein (MP) concept, which is defined as the quantity of true protein and amino acids available for absorption by the animal in the small intestine (VAN SOEST, 1994). Metabolizable protein in feeds is calculated as the sum of rumen synthesized microbial crude protein (MCP), rumen undegradable feed crude protein (RUP) and endogenous crude protein (ECP). The MCP values are a function of the amount of the dietary crude protein that is degradable in the rumen (RDP). Requirements are met by adding RDP and RUP because animal N requirements for high producing animals cannot be met only by MCP produced from RDP and non-protein $\mathrm{N}$ (NRC, 2001).

Urinary $\mathrm{N}$ excretion is highly correlated with $\mathrm{N}$ intake (KEBREAB et al., 2010) since urea excreted in urine is composed of excess absorbed $\mathrm{N}$, and therefore, is highly correlated with RDP intake and animal $\mathrm{N}$ requirements. However, $\mathrm{N}$ excreted in feces is usually less affected by dietary $\mathrm{N}$ content (KAUFFMAN \& ST-PIERRE，2001; COLMENERO \& BRODERICK, 2006) because it is composed of indigestible protein. One 
approach to reduce $\mathrm{N}$ excretion would be to match $\mathrm{N}$ intake with requirement, because most diets formulated for high producing animals usually have excess $\mathrm{N}$. A reduction of dietary crude protein from 19 to $15 \%$ did not affected milk yield and reduced urinary $\mathrm{N}$ excretion significantly in early to mid-lactation cows (CASTILLO et al., 2001a). Similar results were presented by Broderick et al. (2003) who fed lactating cows diets containing crude protein varying from 15.1 to $18.4 \%$ and found that beyond $16.7 \% \mathrm{CP}$, milk yield was not affect by dietary protein content and from 15.1 to $16.7 \%$, the increments in milk yields were modest. However, urinary $\mathrm{N}$ decreased linearly from 35 to $23 \%$ of dietary $\mathrm{N}$ when dietary $\mathrm{CP}$ was decreased from 18.4 to $15.1 \%$ (BRODERICK, 2003). Groff and Wu (2005) found no reduction in milk yield and small differences in milk fat and protein contents when Holstein cows were fed diets varying from 15.7 to 19.2\%. Urinary $\mathrm{N}$ concentration decreased from 7.3 to $5.8 \mathrm{~g} / \mathrm{L}$ of urine (GROFF \& WU, 2005). Børsting et al. (2003) suggested that if dietary RDP contents were reduced to a level equivalent to the maximum capacity of microbes to synthesize protein, dietary $\mathrm{N}$ could be reduced, and RUP would be balanced to meet the rest of $\mathrm{N}$ animal requirement. This approach would reduce $\mathrm{N}$ urinary excretion, because most of RDP would be utilized by microbial production and RUP would be balanced to meet animal amino acid requirements. This hypothesis agrees well with the results of Castillo et al. (2001a), in which urinary $\mathrm{N}$ excretion increased with increased dietary protein degradability and apparent fecal $\mathrm{N}$ excretion was not affected by protein degradability. However, two main problems are evident with this approach. Firstly, RUP sources are generally expensive and can increase diet costs significantly. Secondly, the estimation of RDP and RUP content of feeds are based on digestion and passage rate of protein assumptions, which can have high animal variability and are difficult to measure simultaneously. Therefore, the estimation of amino acid contents of RUP can have a high variability, decreasing the accuracy in estimating amino acid composition of RUP in feeds.

Energy and Protein Synchronism. The synchrony of energy and protein supply in the rumen has been studied to account for optimal microbial protein synthesis (NOCEK \& RUSSELL, 1988). Castillo et al. (2001b) studied urinary and fecal $\mathrm{N}$ excretions of dairy cows fed isoenergetic diets with energy sources varying in digestibility. Dairy cows fed high digestible carbohydrate sources had increased urinary $\mathrm{N}$ excretion. The increased urinary $\mathrm{N}$ excretion was explained by increased ruminal absorption of $\mathrm{NH}_{3}$ and also by increased amino acid deamination (CASTILLO et al., 2001b). Fecal $\mathrm{N}$ in the same study was not affected by carbohydrate rumen digestibility. Castillo et al. (2001b) also reported that efficiency of $\mathrm{N}$ utilization improved with an intermediate digestibility (corn based starch) carbohydrate source due to the change in the site of starch digestion from the rumen to the large intestine, shifting $\mathrm{N}$ excretion from urine to feces. Weiss et al. (2009) fed multiparous lactating cows with diets varying in proportions of alfalfa and corn silage. Fecal $\mathrm{N}$ increased with higher levels of alfalfa and urinary $\mathrm{N}$ excretion represented $41 \%$ and $48 \%$ of $\mathrm{N}$ excretion when dietary alfalfa was $75 \%$ and $25 \%$ of dietary forage, respectively. Changes in urinary and fecal $\mathrm{N}$ excretion were explained by 
changes in $\mathrm{N}$ and carbohydrate digestibility. Broderick (2003) fed lactating cows with varying levels of protein and energy. They found that fecal $\mathrm{N}$ excretion was not affected by source of dietary carbohydrate, however, they observed linear decreases in urinary excretion of urea $\mathrm{N}$ and total $\mathrm{N}$ when dietary NDF was reduced from $36 \%$ to $28 \%$. Reductions in urinary $\mathrm{N}$ excretion were explained by a higher non-fiber carbohydrate content of diets with reduced dietary NDF that caused a higher efficiency of $\mathrm{N}$ utilization in cows fed increased levels of energy. Kebreab et al. (2010) showed that as metabolizable energy increased, milk $\mathrm{N}$ increased at the expense of urinary $\mathrm{N}$. Therefore, the synchrony of dietary energy and protein sources and digestibility seem to be a promising way to reduce $\mathrm{N}$ excretion, because microbial utilization of $\mathrm{N}$ is optimized and absorption of urea and $\mathrm{NH}_{3}$ are reduced.

Phosphorus is second only to calcium in abundance in the body of animals, with about $80 \%$ of the body $\mathrm{P}$ located in the skeleton, the remaining $20 \%$ having essential metabolic function in cell contents and cell walls (VEUM, 2010). Phosphorus requirements for various species of farm animals is periodically reviewed and summarized in publications such as the NRC (2001). The requirements are calculated based on $\mathrm{P}$ digestibility of feedstuff and absorbed $\mathrm{P}$ requirement to support maintenance, growth, pregnancy and lactation.

Livestock utilize $\mathrm{P}$ inefficiently, excreting 60 to $80 \%$ of that consumed. When animals are fed above the requirement, most of the $\mathrm{P}$ will be excreted to the environment. Kebreab et al. (2005) found that there is a linear relationship between $\mathrm{P}$ intake and excretion in feces. Several surveys (e.g.,
SATTER \& WU, 1999) have revealed that dairy producers in the United States feed 0.45 to $0.50 \%$ dietary $\mathrm{P}$, which is in excess of recommendations by NRC (2001). Increased $P$ excretion creates challenges for environmental sustainability. For example, concentrated animal agriculture has been identified as a significant source of $\mathrm{P}$ contamination of surface water in the United States (SMITH \& ALEXANDER, 2000). Apart from dietary strategy such as reduced $\mathrm{P}$ content in diet and increased energy density to reduce $\mathrm{P}$ loading in the environment (KEBREAB et al., 2005), there are several $\mathrm{P}$ removal technologies available. These technologies include chemical precipitation, biological $\mathrm{P}$ removal, constructed wetlands, ionexchange, and crystallization (MORSE et al., 1998). We will limit the discussion to crystallization methods because it is the most promising technology for removing $\mathrm{P}$ from animal manure.

Crystallization. The technique not only removes high levels of $\mathrm{P}$, but it recovers it as useful products such as struvite, calcium phosphate, and hydroxyapatite (WANG et al., 2005). Struvite is the common name for magnesium ammonium phosphate hexahydrate, or MAP (MgNH4-PO4.6H2O), and its constituent ions are among the most predominant in anaerobic swine lagoon effluent (NELSON et al., 2003). Struvite is a promising slow-release fertilizer, with higher purity and lower heavy metal content than commercial phosphate fertilizer. Struvite has been successfully recovered from swine and dairy operations and used as fertilizer in Japan, USA and Belgium (UENO \& FUJII, 2001; MOERMAN et al., 2009). Jordaan et al. (2010) achieved $80 \%$ P removal with high $\mathrm{pH}$ in manure and suggested that struvite precipitation is a 
viable method of $\mathrm{P}$ removal from anaerobically digested swine manure.

The soaring demand for animal products will have serious implications for environmental sustainability in the next few decades. Therefore, it is imperative that technological innovations in animal production cope with increases in production to reduce the carbon footprint and ensure sustainability of animal agriculture. The paper reviewed current practices that offer reductions in GHG emissions, $\mathrm{N}$, and $\mathrm{P}$ excretions to the environment. The technologies need to be implemented on a wider scale to ensure their effectiveness and research into new innovations should continue hand in hand with increasing efficiency and production of animal products.

\section{REFERENCES}

ANTAL, M.J.; GRØNLI, M. The Art, science, and technology of charcoal production. Industrial and Engineering Chemistry Research, v.42, n.8, p.16191640, 2003.

ARMENTANO, L.; PEREIRA, M. Measuring the effectiveness of fiber by animal response trials. Journal of Dairy Science, v.80, n.7, p.1416-1425, 1997.

BALCH, W.E.; FOX, G.E.; MAGRUM, L.J. Methanogens: reevaluation of a unique biological group. Microbiological Reviews, v.43, n.2, p.260-296, 1979.

BEAUCHEMIN, K.A.; KREUZER, A.D.M.; O'MARA, B.F.;

MCALLISTER, T.A. Nutritional management for enteric methane abatement: a review. Australian Journal of Experimental Agriculture, v.48, n.2, p.21-27, 2008.
BEAUCHEMIN, K.A.; MCGINN, S.M.; MARTINEZ, T.F.;

MCALLISTER, T.A. Use of condensed tannin extract from quebracho trees to reduce methane emissions from cattle. Journal of Animal Science, v.85, n.8, p.1990-1996, 2007.

BIRD, S.H.; HEGARTY, R.S.; WOODGATE, R. Modes of transmission of rumen protozoa between mature sheep. Animal Production Science, v.50, n.6, p.414417, 2010.

BØRSTING, C.F.; KRISTENSEN, T.; MISCIATTELLI, L.; HVELPLUND, T.; WEISBJERG, M.R. Reducing nitrogen surplus from dairy farms. Effects of feeding and management. Livestock Production Science, v.83, n.2, p.165-178, 2003.

BRODERICK, G.A. Effects of Varying Dietary Protein and Energy Levels on the Production of Lactating Dairy Cows. Journal of Dairy Science, v.86, n.4, p.1370-1381, 2003.

BUSQUET, M.; CALSAMIGLIA, S.; FERRET, A.; CARRO, M.D.; KAMEL, C. Effect of garlic oil and four of its compounds on rumen microbial fermentation. Journal of Dairy Science, v.88, n.12, p.4393-4404, 2005.

CANTRELL, K. B.; DUCEY, T; RO, K.S.; HUNT, P.G. Livestock waste-tobioenergy generation opportunities. Bioresource Technology, v.99, n.17, p.7941-7953, 2008.

CANTRELL, K.; RO, K.; MAHAJAN, D.; ANJOM, M.; HUNT, P.G. Role of thermochemical conversion of livestock waste-to-energy treatments: obstacles and opportunities. Industrial and Engineering Chemistry Research, v.46, n.26, p.8918-8927, 2007. 
CASTILLO, A.R.; KEBREAB, E.; BEEVER, D.E.; BARBI, J.H.; SUTTON, J.D.; KIRBY, H.C.; FRANCE, J. The effect of energy supplementation on nitrogen utilization in lactating dairy cows fed grass silage diets. Journal of Animal Science, v.79, n.1, p.240-246, 2001a.

CASTILLO, A.R.; KEBREAB, E.; BEEVER, D.E.; BARBI, J.H.; SUTTON, J.D.; KIRBY, H.C.; FRANCE, J. The effect of protein supplementation on nitrogen utilization in grass silage diets by lactating dairy cows. Journal of Animal Science, v.79, n.1, p.247-253, 2001b.

\section{CLIMATE CHANGE CENTRAL. The}

Alberta Offset System. Available at: $<$ http://carbonoffsetsolutions.climatechan gecentral.com/policy-regulation/albertaoffset-system>. Accessed on: March 22, 2011.

COLMENERO, J.J.O.; BRODERICK, G.A. Effect of dietary crude protein concentration on milk production and nitrogen utilization in lactating dairy cows. Journal of Dairy Science, v.89, n.5, p.1704-1712, 2006.

COOPRIDER, K.L.; MITLOEHNER, F.M.; FAMULA, T.R.; KEBREAB, E; VAN EENENNAAM, A.L. Feedlot efficiency implications on greenhouse gas emissions and sustainability. Journal of Animal Science, v.89, n.8, p.2643-56, 2011.

CZERKAWSKI, J.W. The effect on digestion in the rumen of a gradual increase in the content of fatty acids in the diet of sheep. British Journal of Nutrition, v.20, n.4, p.833-842, 1966.

DESUTTER, T.M., HAM, J.M. Lagoonbiogas emissions and carbon balance estimates of a swine production facility. Journal of Environmental Quality, v.34, n.1, p.198-206, 2005.
EUGENE, M.; MASS, D.; CHIQUETTE, J.; BENCHAAR, C. Meta-analysis on the effects of lipid supplementation on methane production in lactating dairy cows. Canadian Journal of Animal Science, v.88, n.2, p.331-334, 2008.

FOOD AND AGRICULTURE ORGANIZATION OF THE UNITED

NATIONS. FAO. Greenhouse gas emissions from the dairy sector. A life cycle assessment. Available at $<$ http://www.fao.org/docrep/012/k7930 e/k7930e00.pdf $>$. Accessed on March 22, 2011.

GROFF, E.B.; WU, Z. Milk production and nitrogen excretion of dairy cows fed different amounts of protein and varying proportions of alfalfa and corn silage. Journal of Dairy Science, v.88, n.10, p.3619-3632, 2005.

GUAN, H.; WITTENBERG, K.M.; OMINSKI, K.H.; KRAUSE, D.O.

Efficacy of ionophores in cattle diets for mitigation of enteric methane. Journal of Animal Science, v.84, n.7, p.18961906, 2006.

HEGARTY, R.S. Reducing rumen methane emissions through elimination of rumen protozoa. Australian Journal of Agricultural Research, v.50, n.8, p.1321-1327, 1999.

HOOK, S.E.; NORTHWOOD, K.S.; WRIGHT, A.D.G.; MCBRIDE, B.W. Long-term monensin supplementation does not significantly affect the quantity or diversity of methanogens in the rumen of the lactating dairy cow.

Applied and Environmental Microbiology, v.75, n.2, p.374-380, 2009. 
HOOK, S.E.; WRIGHT, A.D.; MCBRIDE, B.W. Methanogens: Methane Producers of the Rumen and Mitigation Strategies. Archaea, v.2010, p.1-11, 2010.

HUNGATE, R. E.; SMITH, W.; BAUCHOP, T.; YU, I.; RABINOWITZ, J. C. Formate as an intermediate in the bovine rumen fermentation. Journal of Bacteriology, v.102, n.2, p.389-397, 1970.

\section{INTERGOVERNMENTAL PANEL} ON CLIMATE CHANGE - IPCC.

Guidelines for National Greenhouse Gas Inventories. Hayama, Kanagawa, Japan, 2006. Available at: <http://www.ipcenggip.iges.or.jp>. Accessed on: March 22, 2011.

JOHNSON, K.A.; JOHNSON, D.E. Methane emissions from cattle. Journal of Animal Science, v.73, n.8, p.24832492, 1995.

JORDAAN, E.M.; ACKERMAN, J.; CICEK, N. Phosphorus removal from anaerobically digested swine wastewater through struvite precipitation. Water Science and Technology, v.61, n.12, p.3228-3234, 2010.

KAUFFMAN, A.J.; ST-PIERRE, N.R. The relationship of milk urea nitrogen to urine nitrogen excretion in Holstein and Jersey cows. Journal of Dairy Science, v.84, n.10 p.2284-2294, 2001.

KEBREAB, E.; STRATHE, A.B.; DIJKSTRA, J.; MILLS, J.A.N.; REYNOLDS, C.K.; CROMPTON, L.A.; YAN, T; FRANCE, J. Energy and protein interactions and their effect on nitrogen excretion in dairy cows. In: CROVETTO, M. Energy and Protein Metabolism and Nutrition, n. 127, p.417-425, 2010.
KEBREAB, E.; CLARKE, K.; WAGNER-RIDDLE, C.; FRANCE, J. Methane and nitrous oxide emissions from Canadian animal agriculture - a review. Canadian Journal of Animal Science, v.86, n.2, p.135-158, 2006.

KEBREAB, E.; SHAH, M.A.; BEEVER, D.E.; HUMPHRIES, D.J.; SUTTON, J.D.; FRANCE, J.; MUELLERHARVEY, I. Effects of contrasting forage diets on phosphorus utilisation in lactating dairy cows. Livestock

Production Science, v.93, n.2, p.125135, 2005.

MARTIN, C.; MORGAVI, D. P.; DOREAU. M. Methane mitigation in ruminants: from microbe to the farm scale. Animal, v.4, n.3, p.351-365, 2010.

MCGINN, S.M.; BEAUCHEMIN, K.A.; COATES, T.; COLOMBATTO, D. Methane emissions from beef cattle: effects of monensin, sunflower oil, enzymes, yeast, and fumaric acid.

Journal of Animal Science, v.82, n.11, p.3346-3356, 2004.

MIAO, X.; WU, Q. Biodiesel production from heterotrophic microalgal oil.

Bioresource Technology, v.97, n.6, p.841-846, 2006.

MOERMAN, W.; CARBALLA, M.; VANDEKERCKHOVE, A.; DERYCKE, D.; VERSTRAETE, W. Phosphate removal in agro-industry: pilot- and fullscale operational considerations of struvite crystallization. Water Research, v.43, n.7, p.1887-1892, 2009.

MOHAN, D.; PITTMAN, C.U.; STEELE, P.H. Pyrolysis of Wood/Biomass for Bio-oil: a critical review. Energy and Fuels, v.20, n.3, p.848-889, 2006. 
MORSE, G. K.; BRETT, S. W.; GUY, J. A.; LESTER, J. N. Review: phosphorus removal and recovery technologies. Science of The Total Environment, v.212, n.1, p.69-81, 1998.

MUCK, R.E. Urease activity in bovine feces. Journal of Dairy Science, v.65, n.11, p.2157-2163, 1982.

NELSON, N. O.; MIKKELSEN, R. L; HESTERBERG, D. L. Struvite precipitation in anaerobic swine lagoon liquid: effect of $\mathrm{pH}$ and $\mathrm{Mg}: \mathrm{P}$ ratio and determination of rate constant.

Bioresource Technology, v.89, n.3, p.229-236, 2003.

NOCEK, J.E.; RUSSELL, J.B. Protein and energy as an integrated system. Relationship of ruminal protein and carbohydrate availability to microbial synthesis and milk production. Journal of Dairy Science, v.71, n.8, p.20702107, 1988.

NATIONAL RESEARCH COUNSIL NRC. Nutrient Requirements of Dairy Cattle. 7.ed, Washington DC: National Academic Press, 2001. 381p.

ODONGO, N.E.; BAGG, R.; VESSIE, G.; DICK, P.; OR-RASHID, M.M.; HOOK, S.E.; GRAY, J.T.; KEBREAB, E.; FRANCE, J.; MCBRIDE, W. Longterm effects of feeding monensin on methane production in lactating dairy cows. Journal of Dairy Science, v.90, n.4, p.1781-1788, 2007.

PLAIZIER, J.C.; KRAUSE, D.O.; GOZHO, G.N.; MCBRIDE, B.W. Subacute ruminal acidosis in dairy cows: the physiological causes, incidence and consequences. The Veterinary

Journal, v.176, n.1, p.21-31, 2008.
PUCHALA, R.; MIN, B.R.; GOETSCH, A.L.; SAHLU, T. The effect of a condensed tannin-containing forage on methane emission by goats. Journal of Animal Science, v.83, n.1, p.182-186, 2005.

RUSSELL, J. B.; STROBEL, H.J. Effect of ionophores on ruminal fermentation. Applied Environmental Microbiology, v.55, n.1, p.1-6, 1989.

SATTER, L. D.; Z. WU. New strategies in ruminant nutrition. In: SOUTHWEST NUTRITION AND MANAGEMENT CONFERENCE, 1999, Tucson. Proceedings... Tucson: University of Arizona, 1999. p.1-24.

SCHNEIDER, S.H. The Green House Effect: Science and Policy. Science, v.243, n.4892, p.771-781, 1989.

SHARP, R.; ZIEMER, C.J.; STERN, M.D.; STAHL, D.A. Taxonspecific associations between protozoal and methanogen populations in the rumen and a model rumen system, FMES Microbiology Ecology, v.26, n.2 p.7178, 1998.

SMITH, R. A.; ALEXANDER, R.B. Sources of nutrients in the nation's watersheds. In: MANAGING NUTRIENTS AND PATHOGENS FROM ANIMAL AGRICULTURE, 2000, Ithaca. Proceedings... Ithaca: Natural Resource, Agriculture, and Engineering Service, 2000. p.13-21.

STEEN, I. Phosphorus availability in the 21st Century: management of a nonrenewable resource. Phosphorus and Potassium, v.217, n.5, p.25-31, 1998.

TAMMINGA, S. Nutrition management of dairy cows as a contribution to pollution control. Journal of Dairy Science, v.75, n.1, p.345-357, 1992. 
TAVENDALE, M.H.; MEAGHER, L.P.; PACHECO, D.; WALKER, N.; ATTWOOD, G.T.; SIVAKUMARAN, $S$. Methane production from in vitro rumen incubations with Lotus pedunculatus and Medicago sativa, and effects of extractable condensed tannin fractions on methanogenesis. Animal Feed Science and Technology, v.123/124, p.403-419, 2005.

JONGBLOED, A.W.; LENIS, N.P. Environmental concerns about animal manure. Journal of Animal Science, v.76, p.2641-2648, 1998.

\section{ENVIRONMENTAL PROTECTION} AGENCY - EPA. 2007 Inventory of U.S. Greenhouse Gas Emissions and Sinks: 1990-2005. EPA Report 430-R07-002. Available at:

$<$ http://www.epa.gov/climatechange/emis sions/downloads06/07CR.pdf $>$ Accessed on: March 22, 2011.

COLLEGE OF AGRICULTURAL AND ENVIRONMENTAL SCIENCES CAES. Keeping California's dairy industry globally competitive. Davis: University of California, 2008.

TUNG, R.S.; KUNG JUNIOR, L. In vitro effects of a thiopeptide and monensin on ruminal fermentation of soluble carbohydrates. Journal of Dairy Science, v.76, n.4, p.1083-1090, 1993.

UENO, Y.; FUJII, M. Three years experience of operating and selling recovered struvite from full-scale plant. Environmental Technology, v.22, n.11, p.1373-1381, 2001.

USUI, N.; IKENOUCHI, M. The biological $\mathrm{CO}_{2}$ fixation and utilization project by RITE(1): Highly-effective photobioreactor system. Energy Conversion and Management, v.38, p.487-492, 1997. Suppl.1.
VAN SOEST, P.J. Nutritional ecology of the ruminant. 2.ed. New York: Cornell University Press, 1994. 476p.

VAN VUGT, S.J.; WAGHORN, G.C.; CLARK, D.A.; WOODWARD, S.L. Impact of monensin on methane production and performance of cows fed forage diets. In: NEW ZEALAND SOCIETY OF ANIMAL PRODUCTION, 2005, Mosgiel. Proceedings... Mosgiel: New Zealand Society of Animal Production, 2005. p.362-366.

VEUM, T.L. Phosphorus and Calcium nutrition and metabolism. In: VITTI, D.M.S.S.; KEBREAB, E. Phosphorus and Calcium Utilization and Requirements in Farm Animals. Wallingford: CAB International, 2010. p.94-111.

WAGHORN, G.C.; CLARK, H.; TAUFA, V.; CAVANAGH, A. Monensin controlled release capsules for improved production and mitigating methane in dairy cows fed pasture. NEW ZEALAND SOCIETY OF ANIMAL PRODUCTION, 2007, Mosgiel. Proceedings... Mosgiel: New Zealand Society of Animal Production, 2007. p.266-271.

WANG, J.; BURKEN, J. G.; ZHANG, X.; SURAMPALLI, R. Engineered struvite precipitation: impacts of component-ion molar ratios and $\mathrm{pH}$. Journal of Environmental Engineering, v.131, n.10, p.1433-1440, 2005.

WEISS, W.P.; WILLET, L.B.; STPIERRE, N.R.; BORGER, D.C., MCKELVEY, T.R.; WYATT, D.J. Varying forage type, metabolizable protein concentration, and carbohydrate source affects manure excretion, manure ammonia, and nitrogen metabolism of 
dairy cows. Journal of Dairy Science, v.92, n.11, p.5607-5619, 2009.

WHITELAW, F.G.; EADIE, J.M.; BRUCE, L.A.; SHAND, W.J. Methane formation in faunated and ciliate-free cattle and its relationship with rumen volatile fatty acid proportions. British Journal of Nutrition, v.52, n.2, p.261275, 1984.

WHITFORD, M.F.; TEATHER, R.M.; FORSTER, R. Phylogenetic analysis of methanogens from the bovine rumen. BMC Microbiology, v.1, p.1-5, 2001.

WRIGHT, A.D.; AUCKLAND, C.H.; LYNN, D.H. Molecular diversity of methanogens in feedlot cattle from Ontario and Prince Edward Island, Canada. Applied and Environmental Microbiology, v.73, n.13, p.42064210, 2007.
WRIGHT, A.D.; KENNEDY, P.; O'NEILL, C.J.; TOOVEY, A.F.; POPOVSKI, S.; REA, S.M.; PIMM, C.L.; KLEIN, L. Reducing methane emissions in sheep by immunization against rumen methanogens. Vaccine, v.22, n.29, p.3976-3985, 2004.

WU, Z; PALMQUIST, D.L. Synthesis and biohydrogenation of fatty acids by ruminal microorganisms in vitro.

Journal of Dairy Science, v.74, n.9, p.3035-3046, 1991.

Data de recebimento: 10/11/2011

Data de aprovação: 15/05/2012 